УДК 340.13

DOI https://doi.org/10.51989/NUL.2021.4.14

\title{
ЯКІСТЬ ЗАКОНОДАВСТВА КРІЗЬ ПРИЗМУ ДОТРИМАННЯ ПРАВИЛ ТА ЗАСОБІВ ЗАКОНОДАВЧОЇ ТЕХНІКИ
}

\section{Міщук Інна Володимирівна,}

кандидат юридичних наук, доцент, завідувач кафедри конституційного права та галузевих дисциплін

Національного університету водного господарства та природокористування

у статті проаналізовані наукові підходи до визначення поняття «якість законодавства» та зроблено висновок, що якість закону включає його змістову досконалість, відповідність формальним вимогам, дотримання процедурних аспектів на етапі прийняття, а також відповідність суспільним потребам та дотримання на етапі правореалізації. Правила та засоби законодавчої техніки віднесені до однієї з характеристик якості законодавства.

Запропоновано правила законодавчої техніки умовно поділити на вимоги щодо змісту (системна узгодженість, відповідність суспільним потребам та актуальність, обгрунтованість, однозначність положень, логічність та ін.) та вимоги щодо форми (мовна досконалість, структурованість, які покликані забезпечити досконалість нормативно-правового акта тощо).

Доведено, що недотримання правил та засобів законодавчої техніки - поширене явище сучасного законотворчого процесу, що негативно впливає на якість усього законодавства. Встановлено, що основними порушеннями є недотримання правила системної узгодженості законодавства, дублювання положень інших нормативно-правових актів, порушення формальних вимог, помилки в термінології.

Проаналізовано причини виникнення помилок, серед яких особливе місце посідає низький рівень культури законотворчості та професіоналізму законотворців, відсутність єдиного системного документа, що узагальнював би чинні правила та засоби конструювання законів. У свою чергу основними напрямками, спрямованими на забезпечення дотримання правил та засобів законодавчої техніки $\epsilon$, по-перше, оволодіння депутатами необхідними правовими знаннями і застосування їх у практичній діяльності та, по-друге, вдосконалення нормативно-правового регулювання правил та засобів законодавчої техніки, зокрема, розробка та ухвалення спеціального законодавчого акта, в якому знайдуть відображення формальні та змістові вимоги до нормативно-правових актів.

Ключові слова: якість законодавства, законодавча техніка, правила законодавчої техніки, засоби законодавчої техніки.

\section{Mishchuk Inna. Quality of legislation through the prism of compliance with rules and means of legislative equipment}

The article analyzes scientific approaches to defining the concept of "quality of legislation" and concludes that the quality of the law includes its substantive perfection, compliance with formal requirements, compliance with procedural aspects at the stage of adoption, as well as compliance with public needs and compliance at the stage of law enforcement. Rules and means of legislative technique are one of the characteristics of the quality of legislation.

It is proposed to conditionally divide the rules of legislative technique into requirements on the content (system consistency, compliance with social needs and relevance, validity, unambiguity of provisions, logic, etc.) and requirements for the form (linguistic perfection, structure, which are designed to ensure the perfection of the legal act, etc.)

It is proved that non-compliance with the rules and means of legislative technique is a common phenomenon of the modern legislative process and negatively affects the quality of all legislation. It is established that the main violations are non-compliance with the rule of systematic consistency of legislation, duplication of provisions of other regulations, violation of formal requirements, errors in terminology.

The causes of mistakes are analyzed, among which a special place is occupied by the low level of culture of lawmaking and professionalism of lawmakers, the lack of a single system document that would summarize the existing rules and means of lawmaking. The main areas aimed at ensuring compliance with the rules and means of legislative technique are, firstly, 
the acquisition by deputies of the necessary legal knowledge and their application in practice and, secondly, improvement of normative-legal regulation of rules and means of legislative technique, in particular, development and adoption of a special legislative act, which will reflect the formal and substantive requirements for regulations.

Key words: quality of legislation, legislative technique, rules of legislative technique, means of legislative technique.

Постановка проблеми. В умовах проведення правової реформи в Україні одним із першочергових завдань, що потребує вирішення, $\epsilon$ приведення українського законодавства до внутрішньої узгодженості та відповідності правилам та засобам законодавчої техніки. Українське законодавство характеризується недостатнім юридико-технічним рівнем нормативно-правових актів. Велика кількість зауважень стосується суперечностей між різними правовими актами, їхньої невідповідності Конституції України та іншим законам, недотримання термінології, вимог правопису тощо.

Активна законотворча діяльність Верховної Ради України останнього скликання актуалізує дослідження якості законодавства, особливо крізь призму дотримання депутатами правил та засобів законодавчої техніки.

Аналіз наукових досліджень. Правила та засоби законодавчої техніки активно досліджували такі провідні науковці, як О.В. Богачова, Ж.О. Дзейко, О.Л. Копиленко, А.А. Мельник, Б.Е. Наставний, С.В. Поленіна, В.І. Риндюк, I.I. Шевчук, В.С. Щербина та інші вчені. Однак питання впливу правил та засобів законодавчої техніки на якість законодавства потребує подальших теоретичних досліджень.

Мета та завдання дослідження. Мета статті - проаналізувати значення правил та засобів законодавчої техніки у формуванні якісного законодавства.

Виклад основного матеріалу. Якість закону - це, беззаперечно, найважливіша його характеристика, яка активно досліджується на теоретичному рівні. Наукові погляди на розуміння якості закону переважно збігаються, хоч і можуть торкатися різних його сторін, зокрема, соціальної, економічної, філософської та правової. Ми звернемо увагу саме на правову сторону. Так, А.С. Стащенко під якістю закону пропонує розуміти «його здатність правильно відтворювати у правових нормах специфіку регульованих ним суспільних відносин і безпосередньо регулювати відносини, запобігаючи негативним (тобто незаконним) соціальним діям учасників правовідносин» [13, с. 24]. Ми погоджуємося з такою думкою, однак вважаємо, що автор охарактеризував лише один з аспектів якості закону, а саме поняття $€$ дещо ширшим і включає також інші вимоги.

М.Л. Легін зазначає, що якість закону полягає в тому, що він має бути правовим і базуватись на гармонійному поєднанні традиційних форм права, притаманних для певного суспільства. Якість закону необхідно розглядати також через його форму як зовнішній вираз нормативно-правового акта - письмовий документ і зміст - та як сукупність нормативно-правових приписів [14, с. 197]. Своєю чергою А.А. Мельник, яка досліджує якість закону в технікоюридичному аспекті, зазначає, що «якість закону полягає в сукупності правових властивостей останнього щодо форми, характеризує ступінь його відповідності правилам і прийомам законодавчої техніки та сприяє оптимізації законотворчості й ефективності законодавства» [6, с. 42].

Не можна не погодитися з С.В. Поленіною, яка зазначає, що якість окремого закону охоплюється вимогами, які висуваються до якості нормативних приписів, що в ньому містяться, але не вичерпується ними. На рівні окремого закону термін «якість» ускладнюється за рахунок вимог до внутрішньої логічної погодженості та здатності до взаємодії приписів, які в ньому містяться [10, с. 12$]$.

Ми підтримуємо позицію попередніх авторів і вважаємо, що якість закону включає його змістову досконалість, відповідність формальним вимогам, дотримання процедурних аспектів на етапі прийняття, а також відповідність суспільним потребам та дотримання на етапі правореалізації. Таке розуміння дає змогу виділити правила та засоби законодавчої 
техніки як одну з характеристик якості законодавства.

3 метою розробки проєктів законів, які будуть чітко сформульованими та водночас простими у застосуванні, головним юридичним управлінням Апарату Верховної Ради України підготовлено Правила оформлення проєктів законів та основні вимоги законодавчої техніки (далі - Правила). Загалом правила законодавчої техніки становлять систему вимог і методів створення найбільш доцільних за формою й досконалих за структурою нормативноправових актів. Завдяки їм ці акти характеризуються точністю та визначеністю юридичних форм: речень, словосполучень, окремих термінів, а також ясністю й доступністю мови для адресатів закону, вдалими формулюваннями норм права, вдалою побудовою юридичних конструкцій тощо [19, с. 179].

У Правилах передбачені вимоги до структури законопроєкту, мови і термінології, викладення нормативних положень, оформлення законопроєктів про ратифікацію, внесення змін до законів, вимоги до проєктів постанов Верховної Ради України та супровідних матеріалах, що подаються із законопроєктами [11]. Умовно правила законодавчої техніки можна поділити на вимоги щодо змісту та вимоги щодо форми. Правилами щодо змісту $\epsilon$ системна узгодженість, відповідність суспільним потребам та актуальність, обґрунтованість, однозначність положень, логічність тощо. Своєю чергою, до правил щодо форми належать мовна досконалість, структурованість та інші вимоги, покликані забезпечити довершеність нормативно-правового акта.

Ще одним важливим елементом, дотримання якого забезпечує якість законодавства, $\epsilon$ засоби законодавчої техніки. Так, ж.О. Дзейко засоби законодавчої техніки визначає як допустимі правом явища, за допомогою яких забезпечується досягнення законодавцем мети правового регулювання під час створення і систематизації законів [1, с. 27]. На думку В.С. Щербини, засоби законодавчої техніки - це нематеріальні форми, за допомогою яких закон визначається в різних його виявах, конструкціях. До засобів законодавчої техніки, зокрема, належать: юридичні конструкції; правові фікції; правові пре- зумпції; логіка, стиль і мова закону; юридична термінологія; примітки в законах; додатки до законів; застереження в законах тощо [19, с. 180].

Для наочності пропонуємо розглянути, як недотримання правил та засобів законодавчої техніки впливає на якість законодавства. Так, порушення правила системної узгодженості законодавства призводить до видання взаємовиключних норм або суперечності між нормативно-правовими актами. Як приклад наведемо ст. 2 Кримінального процесуального кодексу України. Законодавець, вказуючи на таке завдання кримінального провадження, як швидке розслідування і судовий розгляд, мав на увазі необхідність дотримання положень про розумність строків кримінального провадження, які випливають зі змісту п. 1 ст. 6 Європейської Конвенції та практики ЄСПЛ. Але «швидке розслідування і судовий розгляд» та «судовий розгляд упродовж розумного строку» - ці поняття не $\epsilon$ ідентичними [5, с. 14].

На наш погляд, протиріччя $є$ і між положенням ст. 53 Конституції України, в якій гарантується право кожного на освіту, та положенням ст. 15 Закону України «Про захист населення від інфекційних хвороб» від 6 квітня 2000 р., в якому зазначено, що дітям, які не отримали профілактичних щеплень згідно з календарем щеплень, відвідування дитячих закладів не дозволяється. По суті положення ст. 15 Закону України «Про захист населення від інфекційних хвороб» позбавляє певну категорію дітей права відвідувати навчальні заклади.

Протилежною помилкою у дотриманні правил та засобів законодавчої техніки, яка негативно впливає на якість законодавства, $\epsilon$ дублювання положень інших нормативно-правових актів. Дублювання у законодавстві - це використання одних і тих самих норм права у різних нормативно-правових актах. Яскравим прикладом названої помилки $\epsilon$ статті законів, що регулюють юридичну відповідальність. Найчастіше справа полягає лише у черговому повторенні загальновідомих положень: особи, винні у порушенні вимог цього Закону, несуть відповідальність згідно із законом. Так, I.I. Шевчук 
зазначає, що дублювання призводить до знецінення нормативно-правових актів та надмірного збільшення обсягу закону $[18$, c. 45]. Також, на наш погляд, дублювання порушує правило внутрішньої узгодженості законодавства, його системності та призводить до недотримання громадянами законодавства та їх недовіри до актів, що видаються парламентом.

На якість законодавства негативно впливає недотримання не лише змістових, а й формальних вимог. Так, поширеними $€$ стилістичні та мовні помилки, які виникають внаслідок порушення орфографічних, лексичних, стилістичних і граматичних норм сучасної української мови.

Як приклад мовних техніко-юридичних помилок можна навести калькування безпосереднє перенесення граматичних форм однієї мови на ґрунт іншої. Зокрема, у ст. 63 Конституції України зазначається, що особа не несе відповідальності за відмову давати показання або пояснення щодо себе, членів сім'ї чи близьких родичів, коло яких визначається законом. В цьому випадку українською мовою правильним було 6 «давати свідчення» або просто «свідчити».

Проаналізувавши техніко-юридичні помилки, В.I. Риндюк зазначає, що основна маса мовних техніко-юридичних помилок у текстах нормативно-правових актів лежить не в площині граматики та синтаксису, а пов'язана з порушенням вимог правотворчої техніки щодо нормативноправового стилю, основними рисами якого $\epsilon$ офіційність, документальність, позбавлений індивідуальності характер викладу, експресивна нейтральність, стереотипність і формалізація, стандартність, ясність, максимальна точність, економічність і повнота, зв'язність і логічна послідовність. За кожною з названих рис нормативно-правового стилю стоять відповідні мовні прийоми та методи правотворчої техніки, порушення яких призводить до мовних техніко-юридичних помилок [12, с. 5-6].

Типовими помилками, які зустрічаються в нормативних актах і негативно впливають на якість законодавства, $\epsilon$ також помилки в термінології. Одні науковці відносять до них змістову неточність дефініції, тавтологію; невідповідність дефініції сучасному розумінню поняття (терміна), невиправдану багатослівність дефініції, наявність різних визначень одного і того самого терміна в різних законодавчих актах [15, с. 41]; інші помилками називають занадто широке або занадто вузьке визначення поняття, тавтологію у визначенні, визначення невідомого через невідоме, неясність та розпливчатість ознак, що входять до визначаючого поняття [3, с. 427-428].

Описані нами порушення правил та засобів законодавчої техніки складають лише невелику частину від їх загальної кількості та, безумовно, потребують подальшого дослідження. Причинами їх виникнення, на наше переконання, $\epsilon$ низький рівень культури законотворчості та професіоналізму законотворців, відсутність єдиного системного документа, що узагальнював би чинні правила та наявні засоби конструювання законів.

Першою проблемою $\epsilon$ низький рівень культури законотворчості. Як слушно зазначає О.Є. Ференс, «якість закону закладається на стадії його творення. Вона залежить від того, наскільки закон відповідатиме потребам та інтересам суспільства, вимогам законодавчої техніки, міжнародним правовим стандартам, а також від того, які імплементаційні механізми у ньому закладені» [16, с. 23]. Відповідно, для того, щоб забезпечити дотримання правил та засобів законодавчої техніки на етапі проєктування законів, перш за все необхідно забезпечити високий рівень професійної майстерності учасників законотворчого процесу.

3 цього приводу М.В. Целуйко та O.В. Усенко зауважують, що законотворчість передбачає наявність у законодавців не тільки загальної культури, а й спеціальних знань, певних навичок, оволодіння мистецтвом формування і формулювання законодавчих актів. Непідготовленість або недостатня підготовленість депутатів до цієї діяльності зумовили недосконалість багатьох прийнятих законів. I цілком можна припустити, що саме ця обставина стала однією з причин необов'язковості виконання закону в масовій свідомості громадян, можливості безкарного його порушення, допустимості «боротьби законів» [17, с. 12] 
Б.E. Наставний, підтверджуючи цю думку, вказує, що законодавча діяльність в Україні свідчить про поширення практики зловживань у сфері законотворчості, що призводить до виникнення помилок у використанні законодавчої техніки [7].

Проаналізувавши законотворчу діяльність українського парламенту протягом останніх років, слід зауважити надзвичайно активне використання народними депутатами права законодавчої ініціативи та динамічну законотворчу діяльність. Як відзначає голова Комітету виборців України О.М. Кошель, у парламенті попереднього (VIII) скликання було представлено приблизно 13 тисяч законопроєктів і проєктів постанов, які не було реальної можливості розглянути, тому коефіцієнт результативності законодавчої діяльності парламентарів був на низькому рівні. Таким чином депутати хотіли продемонструвати виборцям, що вони $\epsilon$ авторами десятків законопроєктів, хоча на практиці ухваленню законів бракувало системності, а ті закони, які були ухвалені, не завжди відповідали принципам законодавчої техніки [2].

Що стосується кадрового потенціалу новообраної Верховної Ради України, то лише $8,5 \%$ народних депутатів раніше працювали з законами - це професійні юристи та адвокати, а 80 \% парламентарів уперше отримали такий статус [8]. Тому актуальним у цьому контексті постає також питання про правову освіту, адже саме вона покликана забезпечити участь в законодавчому процесі кваліфікованих кадрів. Як зазначає Н.М. Оніщенко, проблематика, пов'язана з правовим вихованням, правовою освітою, правовою культурою, правовою свідомістю особи, $\epsilon$ на цей час найбільш актуальною [9, с. 103].

Таким чином, якісна правотворча діяльність, яка включає в себе обов'язкове дотримання правил та засобів законодавчої техніки, безпосередньо залежить від рівня культури законотворчості народних депутатів. Оволодіння депутатами необхідними правовими знаннями і застосування їх у практичній діяльності дозволить згладити цю проблему.

Відсутність єдиного системного документа, що узагальнював би чині правила та наявні засоби конструювання зако- нів, також $€$ причиною недотримання названих правил. Так, О.Л. Копиленко та О.В. Богачова зазначають, що на сьогодні вкрай необхідні вдосконалення нормативно-правового врегулювання відносин у сфері законотворчої діяльності, яке ще не повною мірою відповідає вимогам практики. Значна нормативноправова база у цій сфері (налічується майже 100 актів різної юридичної сили) складається 3 розгалуженого масиву нормативно-правових актів, які не здатні справляти цілісний правовий вплив на законотворчу діяльність [4, с. 7]. Ми погоджуємося, що на сьогодні в нашій державі положення, які регулюють порядок та особливості конструювання законів, можна знайти у низці документів різної юридичної сили. Такий підхід спричиняє недоліки в нормотворчій діяльності, які часом не вдається повністю виправити і на стадії прийняття нормативно-правових актів.

Досліджуючи питання розробки нормативного акта у сфері формалізації вимог до законодавчих актів, необхідно зауважити, що такі спроби вже робилися раніше. Сюди належать розробка проєкту Закону України «Про закони і законодавчу діяльність в Україні» № 894 від 14 травня 2002 р., проєкти Законів України «Про нормативно-правові акти», деякі з яких навіть були прийняті Верховною Радою України, але ветовані Президентом України (наприклад, законопроєкт № 1343-1 від 21 січня 2008 р., прийнятий Верховною Радою України 18 листопада 2009 р.), проєкт Закону України «Про нормативно-правові акти» № 7409 від 1 грудня 2010 р.

Розробка перелічених проєктів нормативних актів мала на меті закріпити на законодавчому рівні комплекс правил, прийомів, засобів створення нормативноправових актів. Удосконалення нормативно-правового регулювання правил та засобів законодавчої техніки в Україні виступає нагальною потребою, тому ми підтримуємо позицію науковців, які наголошують на необхідності розробки та ухвалення в Україні спеціального законодавчого акта, в якому знайдуть відображення формальні та змістові вимоги до нормативно-правових актів. 
Висновки. Недотримання правил та засобів законодавчої техніки $€$ поширеним явищем сучасного законотворчого процесу та негативно впливає на якість усього законодавства. Аналіз законотворчих помилок та їхніх причин дає змогу сформулювати такі основні шляхи покращення якості законодавства, як, по-перше, підвищення рівня культури законотворчості, що зумовлює посилення кадрового потенціалу суб'єктів законотворчості професійними юрис- тами, які матимуть належний рівень професійної спеціалізації (зокрема й у галузі законотворення); по-друге, закріплення та узагальнення правил та засобів законодавчої техніки з метою їх дотримання при створенні та систематизації законодавчих актів, зокрема, шляхом розробки проєкту закону «Про нормативно-правові акти», який повинен визначати основні формальні та змістові вимоги до нормативно-правових актів, та ухвалення його в подальшому.

\section{ЛITEPATУPA:}

1. Дзейко ж.О. Правила і засоби законодавчої техніки: загальна характеристика. Науковий вісник Чернівецького університету : Збірник наук. Праць. 2005. Випуск 286 : Правознавство. С. 25-29.

2. Достижения и провалы Верховной Рады восьмого созыва // URL: https://nv.ua/ukraine/ politics/dostizheniya-i-provaly-verhovnoy-rady-vosmogo-sozyva-50031736.html

3. Кондаков Н.И. Логический словарь-справочник. Москва, 1975. 720 с.

4. Копиленко О.Л., Богачова О.В. Законотворчий процес: стан і шляхи вдосконалення. Наукові записки Інституту законодавства Верховної Ради України. 2010. № 1. С. 5-14.

5. Маляренко В.Т. Новий Кримінальний процесуальний кодекс України: переваги та недоліки. Право України. 2012. № 10. С. 9-19.

6. Мельник А.А. Техніко-юридичний аспект якості закону. 2018. Право і суспільство. № 2. С. 38-43.

7. Наставний Б.Е. Поняття та різновиди помилок у використанні законодавчої техніки: теоретико-правове дослідження : дис. ... канд. юрид. наук : 12.00.01. Київ, 2019. 274 с.

8. Нова Верховна Рада: 8,5\% - юристи та адвокати // Юридична газета online. URL: http://yur-gazeta.com/golovna/nova-verhovna-rada-85--yuristi-ta-advokati.html

9. Оніщенко Н.М. Правосудна діяльність і правове виховання: запити громадянського суспільства. Часопис цивільного та кримінального судочинства. 2016. № 1(28). С. 101-106.

10. Поленина С.В. Качество закона и совершенствование правотворчества. Советское государство и право. 1987. № 7. С. 12-19.

11. Правила оформлення проєктів законів та основні вимоги законодавчої техніки (Методичні рекомендації) URL: https://zakon3.rada.gov.ua/rada/show/n0002451-06?lang=en

12. Риндюк В.I. Техніко-юридичні помилки в нормативно-правових актах: поняття та види. Держава і право. 2012. Вип. 57. С. 5-6.

13. Стащенко А. Про науково-теоретичні проблеми якості закону як основи його ефективності. Підприємництво, господарство і право. 2009. № 11. С. 23-27.

14. Легін Л.М. Поняття та критерії якості закону: проблеми визначення. Проблеми законності. 2016. Вип. 132. С. 196-204.

15. Туранин В. Теория и практика использования законодательных дефиниций: монография. Москва, 2009. 108 с.

16. Ференс О.Є. До проблеми професійної підготовки учасників законотворчої діяльності в Україні: деякі концептуальні аспекти. Наукові записки інституту законодавства Верховної Ради України. 2014. С. 18-23.

17. Целуйко М.В., Усенко О.В. Компетентно-правова культура працівників законодавчої влади України. Актуальні проблеми юридичної науки та практики. 2016. № 1 (2). С. 10-14.

18. Шевчук I.I. Основні способи попередження та подолання правотворчих помилок у законодавстві України. Університетські наукові записки. 2014. № 3 (51). С. 42-47.

19. Щербина В.С. Соціальне призначення засобів законодавчої техніки. Підприємництво, господарство і право. 2017. № 11. С. 179-183. 